
M. F. Geiger

\title{
Adding nuclear rhodopsin data where mitochondrial COI indicates discrepancies - can this marker help to explain conflicts in cyprinids?
}

DOI 10.1515/dna-2015-0020

Received February 27, 2015; accepted October 1, 2015

\begin{abstract}
DNA barcoding is a fast and reliable tool for species identification, and has been successfully applied to a wide range of freshwater fishes. The limitations reported were mainly attributed to effects of geographic scale, taxon-sampling, incomplete lineage sorting, or mitochondrial introgression. However, the metrics for the success of assigning unknown samples to species or genera also depend on a suited taxonomic framework. A simultaneous use of the mitochondrial COI and the nuclear RHO gene turned out to be advantageous for the barcode efficiency in a few previous studies. Here, we examine 14 cyprinid fish genera, with a total of 74 species, where standard DNA barcoding failed to identify closely related species unambiguously. Eight of the genera (Acanthobrama, Alburnus, Chondrostoma, Gobio, Mirogrex, Phoxinus, Scardinius, and Squalius) contain species that exhibit very low interspecific divergence,
\end{abstract}

*Corresponding author: S. Behrens-Chapuis, Zoologisches Forschungsmuseum Alexander Koenig, Leibniz Institute for Animal Biodiversity, Adenauerallee 160, 53113 Bonn, Germany, E-mail: sichapuis@t-online.de

F. Herder, M. F. Geiger, Zoologisches Forschungsmuseum Alexander Koenig, Leibniz Institute for Animal Biodiversity, Adenauerallee 160, 53113 Bonn, Germany

H. R. Esmaeili, Ichthyology Research Laboratory, Department of Biology, College of Sciences, Shiraz University, Shiraz, Iran J. Freyhof, German Centre for Integrative Biodiversity Research (iDiv) Halle-Jena-Leipzig, Deutscher Platz 5a, 04103 Leipzig, Germany

N. A. Hamidan, The Royal Society for the Conservation of Nature - Conservation Division, P.O. Box 1215, Jubaiha 11941, Jordan and Centre for Conservation Ecology and Environmental Science, School of Applied Sciences, Bournemouth University, Poole, BH12 5BB, U.K.

M. Özuluğ, Istanbul University, Science Faculty, Department of Biology, 34134 Vezneciler, Istanbul, Turkey

R. Šanda, National Museum, Václavské nám. 68, 11579 Prague, Czech Republic or haplotype sharing (12 species pairs) with presumed introgression based on mtCOI data. We aimed to test the utility of the nuclear rhodopsin marker to uncover reasons for the high similarity and haplotype sharing in these different groups. The included labeonine species belonging to Crossocheilus, Hemigrammocapoeta, Tylognathus and Typhlogarra were found to be nested within the genus Garra based on mtCOI. This specific taxonomic uncertainty was also addressed by the use of the additional nuclear marker. As a measure of the delineation success we computed barcode gaps, which were present in $75 \%$ of the species based on mtCOI, but in only 39\% based on nuclear rhodopsin sequences. Most cases where standard barcodes failed to offer unambiguous species identifications could not be resolved by adding the nuclear marker. However, in the labeonine cyprinids included, nuclear rhodopsin data generally supported the lineages as defined by the mitochondrial marker. This suggests that mitochondrial patterns were not mislead by introgression, but are caused by an inadequate taxonomy. Our findings support the transfer of the studied species of Crossocheilus, Hemigrammocapoeta, Tylognathus and Typhlogarra to Garra.

Keywords: Barcode gap, mtCOI, nuclear rhodopsin (ncRHO), Cyprinidae, labeonine cyprinids, introgression

\section{Introduction}

The idea of being able to distinguish species and identify whole or even only parts of specimens accurately across any life stage using a short gene sequence received substantial interest in the fields of taxonomy, protection and conservation of biodiversity, observation and management of fisheries, as well as fish trade [1-4]. DNA 
barcoding proved to be a powerful and reliable tool for discriminating a large range of species, including all major taxa of marine as well as freshwater fishes [e.g. 1,5-12]. The tool has gained additional attention among biologists by having the potential to reveal cryptic diversity, especially given the enormous amount of data collected globally, which can easily be used to compare own sequence data on a regional scale. A high level of intraspecific mtCOI divergence is a likely indicator for cryptic diversity, i.e. putative new, or unrecognized species, pronounced phylogeographic structure, but might also result from introgressive hybridization [1015].

The potential of DNA barcoding appears promising, but has not been without controversy. The latter centred on either the suitability of mtCOI as universal marker, or the most meaningful method to delineate species based on molecular data [16-18]. The possibility to distinguish species unambiguously by DNA barcoding depends on the sequence variation within and between the taxa studied. Freshwater fishes, and in particular members of the speciose family Cyprinidae (minnows, carps), are among the animals known for high rates of hybridization and introgression [19-22]. Hybridization may lead to the transfer of mitochondrial DNA into heterospecific populations (i.e. introgression); the mismatch of nuclear population structure and mitochondrial haplotypes may confound analyses based solely on mitochondrial markers, and lead to misidentifications in barcoding routines $[6,23]$.

Here, we focus on cyprinid species that exhibited low interspecific divergence, or haplotype sharing based on mtCOI data in previous studies [10,12]; these allow to critically assess the potential to resolve taxonomic conflicts as well as the discrimination capacity of the nuclear rhodopsin marker (ncRHO). Cyprinids are the most species-rich family of vertebrates in freshwaters of Eurasia, Africa, and North America $[24,25]$. Some of the species, like the common carp, the goldfish, or the zebrafish, have substantial commercial cultural and/or scientific importance, whereas the vast majority of the cyprinid species remain known only to a few specialists $[26,27]$. In order to evaluate the potential of ncRHO to resolve an ongoing taxonomic dispute, we also include labeonine cyprinids (Garra and related genera), characterized by the presence or absence of a conspicuous adhesive organ, the mental disc apparatus. A small or absent disc was interpreted as ancestral character state, whereas a completely developed disc was considered the derived state [28]. More recently, and based on several nuclear genes, it has been considered that the mental disc in labeonine cyprinids has evolved and been reduced independently in several lineages [29]. This new hypothesis was supported by phylogenetic analyses of nuclear and mitochondrial genes in labeonines by Yang et al. [30]. Likewise, mtCOI-based findings in Hamidan et al. [31] and Geiger et al. [10] showed the same pattern with different labeonine genera (defined by the mental disc apparatus) to be nested within Garra, which could be explained by past hybridization events. This pheneticmitochondrial incongruence in the Garra species complex represents an ideal case to be examined by an additional genetic marker with different evolutionary rate and genomic position.

Several studies have tried to overcome uncertainties in species identification derived from analysing exclusively the mtCOI region by supplementing this marker with nuclear sequences [32-35]. The nuclear rhodopsin gene (ncRHO) is an intronless gene [36], which has been recommended for teleost fishes by Sevilla et al. [37], and been applied in different phylogenetic analyses [30,38,39]. A first comparison of mtCOI to ncRHO for species identification in billfishes revealed a discrepancy between both markers in the species-complex of white and striped marlin [40]. A direct comparison of individuals where sequences for both loci were available revealed that those, which are distinguishable by mtCOI lack a clear separation by the nuclear marker and vice versa [40]. In French chubs mtCOI clearly separated the common chub $S$. cephalus from the Catalan chub $S$. laietanus by revealing two divergent haplotype clusters, whereas the topology based on nuclear rhodopsin was uncertain, showing nine different haplotypes with neither correspondence to taxonomy, nor to geography [41]. When identifying cyprinids in the aquarium trade, nuclear rhodopsin results were broadly consistent with mtCOI patterns and morphology although ncRHO failed to distinguish closely related species, but proved to be useful to uncover hybridisation between various species of barbs in the ornamental trade sector [42].

Following the three previously mentioned direct comparisons of mtCOI and ncRHO, we first address the question whether the ncRHO marker has the potential to improve species identification where the taxonomic resolution of mtCOI in cyprinid fishes was not sufficient. We include cases where species exhibit mtCOI barcodes with low interspecific divergence, haplotype sharing or potential introgression ([10], Table S2C). The second focus of this study is on labeonine cyprinid genera, where members of Crossocheilus, Hemigrammocapoeta, 
Tylognathus and Typhlogarra were found to be nested within Garra based on mtCOI data (e.g. [10], Table S2A). We test if the nuclear marker can help to answer the question if this pattern is caused by introgression, or an inadequate taxonomy, and evaluate the discrimination capacity of both markers by checking for the presence of barcode gaps.

\section{Materials and methods}

\subsection{Sampling}

Samples were collected with the aid of numerous colleagues from multiple sites in the Middle East and Europe. Tissue samples were taken from the righthand pectoral fin. Individuals were subsequently fixed in 4-5\% formaldehyde and preserved in $70 \%$ ethanol as vouchers. In total, 193 specimens belonging to 14 cyprinid genera were included in this study. In eight genera (Acanthobrama, Alburnus, Chondrostoma, Gobio, Mirogrex, Phoxinus, Scardinius, Squalius) 'species groups' (in total 49 species) are present, exhibiting low interspecific divergence or haplotype sharing, or an introgression was suspected based on previous findings $[10,12]$. The labeonine cyprinids analysed comprise five genera (Crossocheilus, Hemigrammocapoeta, Tylognathus, Typhlogarra) with seven species, and eighteen species of the genus Garra.

Voucher specimens are deposited in public collections (Istanbul University, Science Faculty, Hydrobiology Museum in Istanbul; Museo Nacional de Ciencias Naturales, Madrid, Spain; Národni Museum, Natural History Museum, Praha, Czech Republic; Personal collection of Maurice Kottelat, Carnol, Switzerland; Zoological Museum of the Department of Biology, College of Sciences, Shiraz University; Zoological Research Museum in Bonn). Detailed specimen data (taxonomy, collection sites, and voucher catalogue numbers) are available at supplemental Table S1 and Figure S1. All data are available via the BOLD portal (project IDs: RHCOI and FFMBH).

\subsection{DNA extraction and PCR}

DNA was extracted using the Macherey \& Nagel NucleoSpin ${ }^{\circledR}$ Tissue kits following the protocol provided by the manufacturer on an Eppendorf EpMotion ${ }^{\circledR}$ pipetting-roboter with vacuum manifold. To amplify the mitochondrial COI barcode region, a fish primer cocktail [43] was used, and if necessary a mammal cocktail [43] in a second attempt. The nuclear rhodopsin data were generated using the primers $\mathrm{RH} 28 \mathrm{~F}$ [39] and $\mathrm{RH} 1039 \mathrm{R}$ [38]. PCR conditions for both markers using Qiagen Multiplex ${ }^{\circledR}$ taq were as follows: $15 \mathrm{~min}$ at $95.0^{\circ} \mathrm{C} ; 10$ cycles of $35 \mathrm{~s}$ at $94.0^{\circ} \mathrm{C}, 90 \mathrm{~s}$ at $52.0-49.0^{\circ} \mathrm{C}$ ("touch-down") and 90 $\mathrm{s}$ at $72.0^{\circ} \mathrm{C}$ followed by 25 cycles of $35 \mathrm{~s}$ at $94.0^{\circ} \mathrm{C}, 90 \mathrm{~s}$ at $55.0^{\circ} \mathrm{C}$ and $90 \mathrm{~s}$ at $72.0^{\circ} \mathrm{C} ; 10 \mathrm{~min}$ at $72.0^{\circ} \mathrm{C}$ and hold at $10.0^{\circ} \mathrm{C}$. The purified PCR products were sent to Macrogen Europe Laboratories for standard Sanger sequencing in both.

\subsection{Analyses}

DNA sequences were assembled, checked for gaps or stop-codons in Geneious Pro (version 7) and aligned using the MUSCLE algorithm [44,45]. The distancebased analyses were conducted with the Spider (Species Identity an Evolution in R) package for $\mathrm{R}$ [46]. The initial pairwise distance matrix was constructed using uncorrected p-distances with missing data treated under the "pairwise deletion" option (Ambiguous Base/ Gap Handling). Application of this genetic distance measure follows the recommendations of Collins at al. [47], as well as Srivathsan and Meier [48], criticizing the ubiquitous use of the Kimura two-parameter (K2P/K80) model [49] for closely related mtCOI sequences. In our case, a direct comparison of uncorrected p-distances and distances generated under the K2P substitution model revealed that the respective genetic distances perform equally well (supplemental Fig. S2, linear regression: mtCOI interspecific distance: $\mathrm{p}$ (uncorr) $<0.0001, \mathrm{r}^{2}=$ 0.99836; mtCOI intraspecific distance: $\mathrm{p}$ (uncorr) $<0.0001$, $\mathrm{r}^{2}=0.99566$; ncRHO interspecific distance: $\mathrm{p}$ (uncorr) $<0.0001, r^{2}=0.99996$; ncRHO intraspecific distance: $\mathrm{p}$ (uncorr) $<0.0001, \mathrm{r}^{2}=1$ ), so the simplest one was chosen. Subsequently, barcode gaps (i.e. the assumption that interspecific- exceeds intraspecific variation, [17]) using the smallest interspecific and maximum intraspecific divergences were computed [46]. Phylogenetic analyses were conducted in MEGA 6.06 [50] and the implemented Modeltest [51] used to determine the best substitution model for each alignment (i.e. the one with the lowest BIC score). Accordingly, the Tamura-3-parameter model [52] with gamma distribution and invariant sites for mtCOI and no invariant sites for ncRHO was chosen to generate neighbour-joining and maximum likelihood trees for visualizing resulting patterns. Robustness of topologies was assessed using a bootstrap resampling strategy with 1000 replicates, treating gaps and missing data with the partial deletion option under $95 \%$ site coverage cutoff. 


\section{Results}

In total we included DNA sequences of 193 specimens of 74 cyprinid species in our analysis (supplemental Table S1); mtCOI fragments had a read length between 540 and 652 base pairs (bp) and nuclear rhodopsin fragments between 743 and $782 \mathrm{bp}$. We compared the divergence levels present based on sequences of the mitochondrial mtCOI and the nuclear rhodopsin marker. Given the nonmonophyletic clustering of Garra in our data based on mtCOI and the previous findings [10, 29, 30], we analysed two different versions of our data: a) with traditional Garra taxonomy - using five different genera; b) a taxonomy placing the species included herein from Crossocheilus, Hemigrammocapoeta, Tylognathus and Typhlogarra to Garra (for more detailed information see Table 1).

\subsection{Sequence divergence mtCOI}

In the labeonine cyprinids, intraspecific uncorrected p-distances of mtCOI range from $0 \%$ to $1.07 \%$ (in Garra sahilia). In Crossocheilus, Hemigrammocapoeta, Tylognathus and Typhlogarra the minimum interspecific p-distances exceed the maximum intraspecific distance. Thesmallest congeneric interspecific distancevalue ranges from $0.46 \%$ to $9.20 \%$ (Garra rossica to G. klatti) (Table 2). In the nine remaining cyprinid genera the intraspecific divergences based on uncorrected p-distances of the mtCOI reach the highest values in Phoxinus phoxinus (5.47\%) and Mirogrex terrasanctae (6.84\%; Table 2). In the genera Chondrostoma (C. kubanicum, C. variabile), Gobio (G. hettitorum, G. microlepidotus), Scardinius (S. hesperidicus, S. racovitzai), and Squalius (S. cephalus, S.

Table 1: Comparison of extent and presence of barcode gaps based on both markers for all 74 cyprinid species. The maximum intraspecific p-distance (\%) is subtracted from the minimum interspecific distance p- distance (\%). Negative values indicate the absence of a barcode gap.

\begin{tabular}{|c|c|c|}
\hline species (former generic placement) & $\begin{array}{l}\text { min interspecific - } \\
\text { max intraspecific } \\
\text { distance }\end{array}$ & $\begin{array}{l}\text { barcode } \\
\text { gap }\end{array}$ \\
\hline Acanthobrama lissneri & $0.33 /-0.26$ & yes / no \\
\hline Acanthobrama marmid & $2.15 /-0.13$ & yes / no \\
\hline Acanthobrama orontis & $1.38 / 0.13$ & yes / yes \\
\hline Acanthobrama persidis & $2.76 / 0$ & yes / neutral \\
\hline Alburnus caeruleus & $0.17 /-0.28$ & yes / no \\
\hline Alburnus heckeli & $0.17 / 0$ & yes / neutral \\
\hline Alburnus sellal & $-0.32 / 0$ & no / neutral \\
\hline Alburnus tarichi & $0.19 /-0.13$ & yes / no \\
\hline Chondrostoma beyshehirense & $0.19 / 0$ & yes / neutral \\
\hline Chondrostoma colchicum & $0.33 / 0$ & yes / neutral \\
\hline Chondrostoma cyri & $-0.17 / 0$ & no / neutral \\
\hline Chondrostoma holmwoodi & $0.74 / 0.13$ & yes / yes \\
\hline Chondrostoma knerii & $0.31 / 0.67$ & yes / yes \\
\hline Chondrostoma kubanicum & $0 / 0$ & neutral / neutral \\
\hline Chondrostoma nasus & $0.02 / 0$ & yes / neutral \\
\hline Chondrostoma phoxinus & $1.30 /-0.01$ & yes / no \\
\hline Chondrostoma prespense & $0.61 / 0$ & yes / neutral \\
\hline Chondrostoma soetta & $0.31 / 0.38$ & yes / yes \\
\hline Chondrostoma variabile & $0 /-0.13$ & neutral / no \\
\hline Garra barreimiae & $5.31 / 0.51$ & yes / yes \\
\hline Garra buettikeri & $0.61 / 0$ & yes / neutral \\
\hline Garra jordanica & $3.68 / 0.13$ & yes / yes \\
\hline Garra (Hemigrammocapoeta) culiciphaga & $6.44 / 1.66$ & yes / yes \\
\hline Garra (Hemigrammocapoeta) elegans & $0.46 / 0.26$ & yes / yes \\
\hline Garra (Tylognathus) festai & $4.31 / 0.90$ & yes / yes \\
\hline Garra ghorensis & $3.68 / 0.26$ & yes / yes \\
\hline
\end{tabular}


Table 1: (continued)

\begin{tabular}{|c|c|c|}
\hline species (former generic placement) & $\begin{array}{l}\text { min interspecific - } \\
\text { max intraspecific } \\
\text { distance }\end{array}$ & $\begin{array}{l}\text { barcode } \\
\text { gap }\end{array}$ \\
\hline Garra gymnothorax & $4.91 /-0.13$ & yes / no \\
\hline Garra (Hemigrammocapoeta) kemali & $2.30 / 0$ & yes / neutral \\
\hline Garra (Crossocheilus) klatti & $2.30 / 0.13$ & yes / yes \\
\hline Garra longipinnis & $5.37 / 0$ & yes / neutral \\
\hline Garra (Hemigrammocapoeta) nana & $4.97 / 1.02$ & yes / yes \\
\hline Garra persica & $2.30 / 0$ & yes / neutral \\
\hline Garra rossica & $8.74 / 1.15$ & yes / yes \\
\hline Garra rufa & $1.46 /-0.77$ & yes / no \\
\hline Garra sahilia & $4.45 / 0.13$ & yes / yes \\
\hline Garra smarti & $1.84 / 0.26$ & yes / yes \\
\hline Garra sp. Mond & $0.33 /-0.13$ & yes / no \\
\hline Garra sp. Orontes & $1.44 / 0.13$ & yes / yes \\
\hline Garra sp. Nahr al Kabir & $1.59 / 0.26$ & yes / yes \\
\hline Garra sp. Kol & $0.89 / 0.13$ & yes / yes \\
\hline Garra sp. Tigris & $0.46 /-0.0002$ & yes / no \\
\hline Garra tibanica & $0.61 / 0$ & yes / neutral \\
\hline Garra variabilis & $6.90 / 1.53$ & yes / yes \\
\hline Garra (Typhlogarra) widdowsoni & $2.76 / 0.26$ & yes / yes \\
\hline Gobio battalgilae & $-0.31 /-0.26$ & no / no \\
\hline Gobio gobio & $1.23 / 0.38$ & yes / yes \\
\hline Gobio gymnostethus & $0.31 / 0$ & yes / neutral \\
\hline Gobio hettitorum & $0 / 0$ & neutral / neutral \\
\hline Gobio insuyanus & $0.15 /-0.13$ & yes / no \\
\hline Gobio kovatschevi & $1.23 / 0.26$ & yes / yes \\
\hline Gobio microlepidotus & $0 / 0$ & neutral / neutral \\
\hline Gonorhynchus adiscus & $6.60 / 0.77$ & yes / yes \\
\hline Gonorhynchus diplocheilus & $6.60 / 0.78$ & yes / yes \\
\hline Mirogrex terrasanctae & $-6.51 /-0.38$ & no / no \\
\hline Phoxinus bigerri & $3.54 / 0.64$ & yes / yes \\
\hline Phoxinus colchicus & $2.74 / 0$ & yes / neutral \\
\hline Phoxinus lumaireul & $2.19 / 0.26$ & yes / yes \\
\hline Phoxinus phoxinus & $-3.60 /-0.26$ & no / no \\
\hline Phoxinus septimaniae & $3.01 /-0.13$ & yes / no \\
\hline Phoxinus strandjae & $1.36 / 0.13$ & yes / yes \\
\hline Scardinius erythrophthalmus & $-0.31 /-0.77$ & no / no \\
\hline Scardinius hesperidicus & $0 / 0$ & neutral / neutral \\
\hline Scardinius plotizza & $-0.15 / 0$ & no / neutral \\
\hline Scardinius racovitzai & $0 / 0$ & neutral / neutral \\
\hline Scardinius scardafa & $-0.61 /-0.26$ & no / no \\
\hline Squalius cappadocicus & $0 / 0$ & neutral / neutral \\
\hline Squalius carinus & $0.31 /-0.38$ & yes / no \\
\hline Squalius cephalus & $0 / 0$ & neutral / neutral \\
\hline Squalius fellowesii & $0.31 / 0.26$ & yes / yes \\
\hline Squalius orientalis & $0.77 / 0$ & yes / neutral \\
\hline Squalius orpheus & $-3.38 /-0.77$ & no / no \\
\hline Squalius pursakensis & $0.15 / 0$ & yes / neutral \\
\hline Squalius recurvirostris & $0.15 / 0$ & yes / neutral \\
\hline Squalius seyhanensis & $0 / 0$ & neutral / neutral \\
\hline
\end{tabular}


Table 2: Summary of the mtCOI- and ncRHO-derived divergence values in $\%$ uncorrected $p$-distance for each genus. Divergence values for the labeonine cyprinids are provided applying also the proposed updated taxonomy, placing the analysed species of Hemigrammocapoeta, Tylognathus, Typhlogarra and Crossocheilus into Garra.

\begin{tabular}{|c|c|c|c|c|c|}
\hline \multirow[b]{2}{*}{ genus } & \multirow[b]{2}{*}{ number species } & \multirow[b]{2}{*}{ number sequences } & \multicolumn{2}{|c|}{ p-distance (\%) mtCOI / ncRHO } & \multirow[b]{2}{*}{$\begin{array}{l}\text { maximum } \\
\text { intraspecific }\end{array}$} \\
\hline & & & $\begin{array}{l}\text { minimum } \\
\text { interspecific }\end{array}$ & $\begin{array}{l}\text { maximum } \\
\text { interspecific }\end{array}$ & \\
\hline Acanthobrama & 4 & 10 & $0.33 / 0$ & $2.76 / 0.38$ & $0.77 / 0.38$ \\
\hline Alburnus & 4 & 12 & $0.17 / 0$ & $0.52 / 0.67$ & $0.49 / 0.67$ \\
\hline Chondrostoma & 11 & 21 & $0 / 0$ & $1.30 / 0.80$ & $0.52 / 0.40$ \\
\hline Gobio & 7 & 15 & $0 / 0$ & $1.23 / 0.38$ & $0.46 / 0.26$ \\
\hline Gonorhynchus & 2 & 3 & $6.60 / 0.77$ & $6.60 / 0.77$ & $0 / 0$ \\
\hline Mirogrex & 1 & 4 & $0.33 / 0$ & $4.89 / 0.38$ & $6.84 / 0.38$ \\
\hline Phoxinus & 6 & 38 & $1.87 / 0$ & $4.47 / 0.90$ & $5.47 / 0.26$ \\
\hline Scardinius & 5 & 13 & $0 / 0$ & $0.61 / 0.51$ & $0.61 / 0.77$ \\
\hline Squalius & 9 & 20 & $0 / 0$ & $1.54 / 0.64$ & $4.29 / 0.90$ \\
\hline total & 49 & 136 & & & \\
\hline Garra: trad. taxonomy & 18 & 42 & $0.46 / 0$ & $9.20 / 2.30$ & $1.07 / 0.77$ \\
\hline Crossocheilus & 1 & 2 & $2.30 / 0.13$ & $2.30 / 0.13$ & $0 / 0$ \\
\hline Hemigrammocapoeta & 4 & 9 & $0.46 / 0.13$ & 4.97 / 1.66 & $0 / 0.38$ \\
\hline Tylognathus & 1 & 2 & $4.46 / 0.90$ & $4.62 / 0.90$ & $0.15 / 0$ \\
\hline Typhlogarra & 1 & 2 & $2.76 / 0.26$ & $2.76 / 0.26$ & $0 / 0$ \\
\hline Garra: new taxonomy & 25 & 57 & $0.46 / 0$ & $9.20 / 2.30$ & $1.07 / 0.77$ \\
\hline total & 25 & 57 & & & \\
\hline
\end{tabular}

seyhanensis, S. cappadocicus) species are present with haplotype sharing (Table 2).

\subsection{Sequence divergence ncRHO}

The minimum interspecific p-distances in labeonine cyprinids exceed the maximum intraspecific distances in Crossocheilus and Tylognathus. In Hemigrammocapoeta and Garra the maximum intraspecific distance is higher (Table 2). Under both concepts (a \& b) intraspecific variation is highest in Garra with $0.77 \%$ (G. rufa; G. variabilis). The smallest congeneric, interspecific distances range from $0 \%$ in G. buettikerii, G. persica, G. tibanica, G. gymnothorax, G. rufa, and G. sp. Mond, to $2.30 \%$ (G. variabilis to G. kemali) (Table 2). In the other cyprinids the genus Squalius exhibits the highest observed intraspecific divergence values ( $0.9 \%$ in S. orpheus) (Table 2 ), whereas species with no within-species variation were found in all genera, except Mirogrex terrasanctae (0.26\%). In species of the genera Phoxinus (P. phoxinus), Scardinius (S. erythrophthalmus) and Squalius (S. carinus, S. orpheus) the maximum intraspecific distance values exceed the maximum interspecific distances. The congeneric, interspecific distances range from $0 \%$ to the highest value of $0.9 \%$ (P. biggeri to P. phoxinus).

\section{3 mtCOI vs. ncRHO distance estimates}

In $92.11 \%$ of the species the smallest interspecific divergence values are higher in mtCOI $(0 \%-6.60 \%)$ than derived from the nuclear marker $(0 \%-2.30 \%)$, regardless of the taxonomic concept applied to the labeonine cyprinids (t-test new taxonomy: $\mathrm{p}$ (same mean) < 0.001; t-test traditional taxonomy: $\mathrm{p}$ (same mean) $<0.01$ ). In $9.21 \%$ of the species (A. caeruleus, A. heckeli, C. knerii, $C$. kubanicum, C. soetta, C. variabile, S. erythrophthalmus), the minimum interspecific divergence derived from the nuclear rhodopsin marker is higher. Under both concepts (a \& b) the maximum intraspecific variation of mtCOI exceeds the values of nuclear rhodopsin in $31.58 \%$ of the species (mtCOI: $0 \%-6.84 \%$ vs. ncRHO: $0 \%-0.9 \%$ ). In $23.68 \%$ of the species (A. lissneri, A. marmid, A. persidis, $A$. caeruleus, A. heckeli, C. kubanicum, C. phoxinus, C. soetta, C. variabile, G. insuyanus, S. erythrophthalmus, S. carinus, G. kemali, G. longipinnis, G. nana, G. rufa, G. sp. Tigris, G. variabilis) the maximum intraspecific distances are higher based on nuclear rhodopsin (t-test for labeonine: new taxonomy $\mathrm{p}$ (same mean) $=0.12$; traditional taxonomy $\mathrm{p}$ (same mean $)=0.05)$. In 22 cyprinids as well as in 12 (new and traditional taxonomy) labeonine species the intraspecific divergences are zero in both markers. 


\subsection{Barcode gap analysis mtCOI}

The sequence divergence of the mtCOI gene reveals clear barcode gaps distinguishing $75 \%$ of the 74 cyprinid species analysed, including the labeonine genera (Figure 1). Twelve percent of the species are neutral, i.e. show equal amounts of inter- and intraspecific variation, and $13 \%$ of the species fall below the 1:1 line (Figure 1). Mirogrex terrasanctae, Phoxinus phoxinus and Squalius orpheus revealed the highest intraspecific variation (Table 1, Figure 1). All labeonine cyprinids are readily distinguished by barcode gaps.

\subsection{Barcode gap analysis ncRHO}

Based on the nuclear rhodopsin marker (proposed updated labeonine taxonomy, Table 1) a clear barcode gap is evident in $39 \%$ of the 74 cyprinid species, and $26 \%$ fall below the 1:1 line, 34\% are neutral. Note that based on ncRHO Garra rufa, as well as Garra gymnothorax, Garra sp. Mond and Garra sp. Tigris lack a clear gap (Figure 1). Squalius orpheus exhibits the highest intraspecific variance (Figure 1).

The direct comparison of both markers applying the proposed updated labeonine taxonomy shows that the standard mtCOI marker allows for the discrimination of a higher number of cyprinid species (Figure 1).

\subsection{Neighbour- joining analysis}

Sequence differences in the nuclear rhodopsin marker did not help to resolve the conflict between morphological

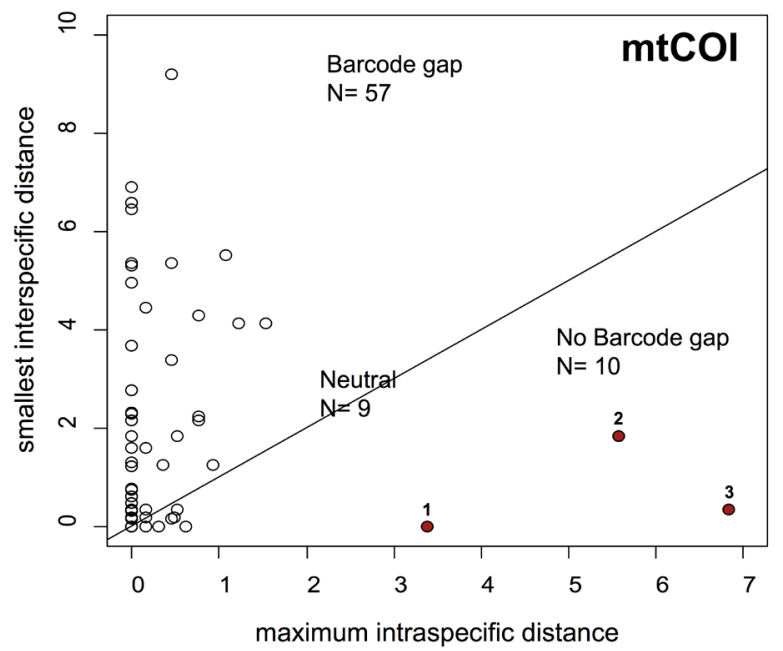

assignment and mtCOI barcode data in most of the cyprinid species analysed (supplemental Figure S3), except in the labeonine genera. Topologies of both labeonine NJ trees (mtCOI and ncRHO) reveal identical phylogenetic relationships for few species only. In most cases the mitochondrial lineages represent well resolved species that are not recovered in the topology based on the nuclear marker (Figures 2 and 3).

\section{7 mtCOI-based topology}

In the labeonine mtCOI tree two main clades are well supported (clade I: Garra rufa group; clade II: Garra variabilis group, Figure 2), and all species show shallow intraspecific and deep interspecific divergences, forming independent clusters in the tree. When considering the traditional labeonine taxonomy, a mismatch in the placement of the different genera is obvious. This is also indicated by the small genetic distances between species of the genus Garra and the species of the genus Crossocheilus, Hemigrammocapoeta, Tylognathus and Typhlogarra studied here. Hemigrammocapoeta elegans is closer to Garra sp. from the river Tigris than to the other three Hemigrammocapoeta species present in this tree. Likewise, Hemigrammocapoeta kemali clusters together with Crossocheilus klatti. They form together with Garra variabilis and Garra rossica a well-supported cluster (Garra variabilis group). In the ML tree the same main clades are recovered, presenting an identical topology with similar node supports (supplemental Fig. S4).

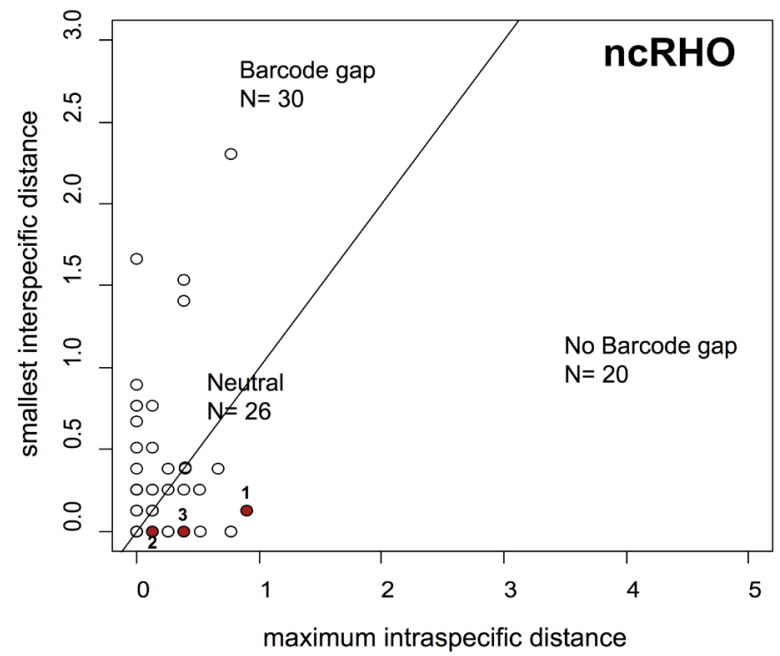

Figure 1: Barcode gap plots showing the maximum intraspecific divergence vs. the smallest interspecific distance based on uncorrected p-distances for 74 cyprinid species. Dots above the 1:1 line indicate the presence of a barcode gap. Three species with increased intraspecific variance (mtCOI or ncRHO) are highlighted by red dots: 1) Squalius orpheus; 2) Phoxinus phoxinus; 3) Mirogrex terrasanctae 


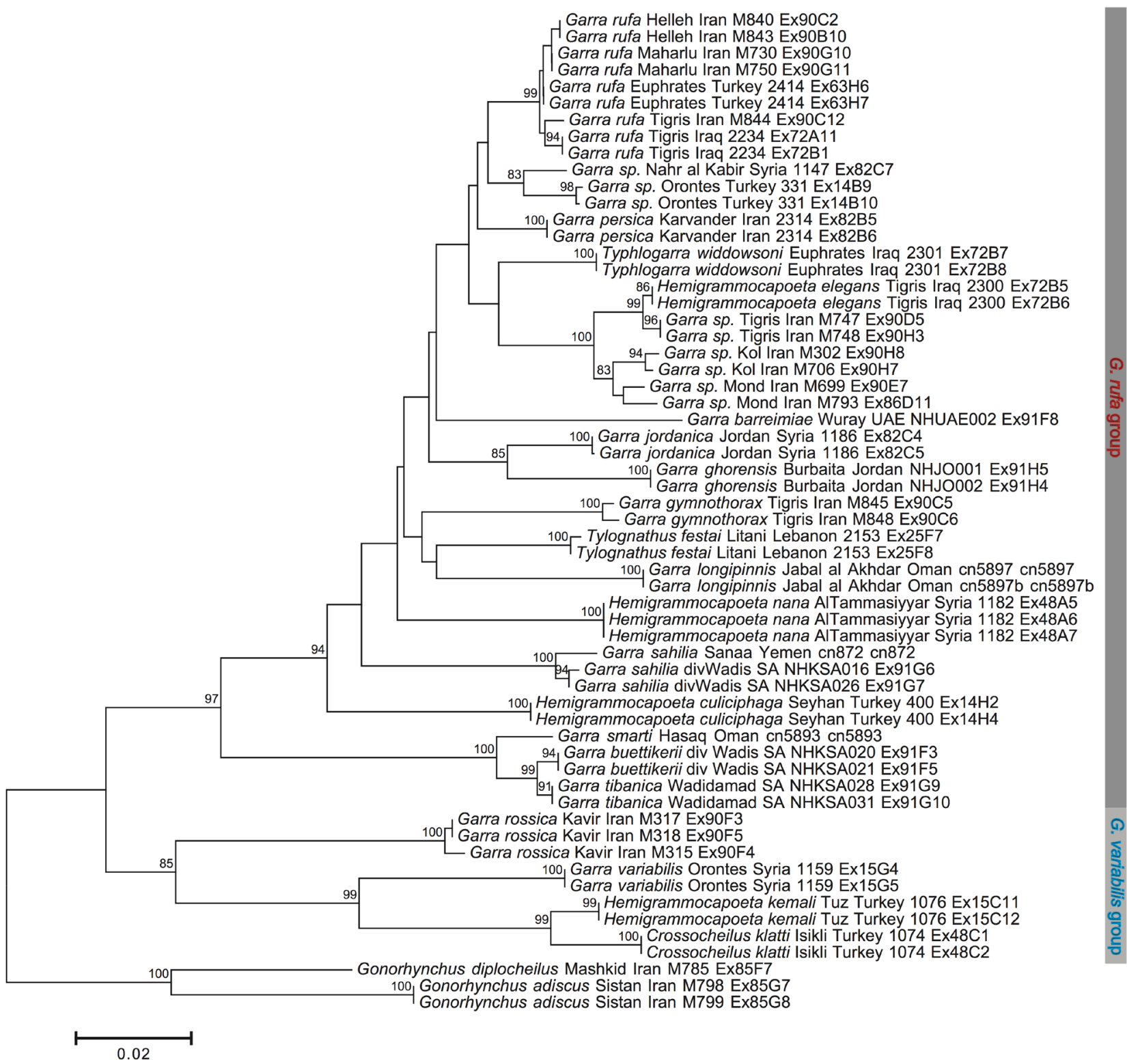

Figure 2: NJ-tree (Tamura 3-parameter model) derived from mtCOI sequences showing the traditional taxonomy. Bootstrap support values below $75 \%$ are hidden.

\subsection{Nuclear rhodopsin-based topology}

The labeonine tree based on nuclear rhodopsin data reflects the same relationships between few species that are recovered as individual clusters, but generally gives less resolution and a number of unresolved nodes; bootstrap support for most deeper nodes is below $75 \%$ and not shown (Fig. 3). The Garra variabilis group is recovered again with four non-overlapping species clusters (Figures 2 and 3), but situated without support inside the whole Garra assemblage. Garra rufa, as well as Garra sp. Mond and Garra gymnothorax are not recovered as monophyletic assemblages, and group together with G. persica, H. elegans and G. sp. Tigris in one clade. Additionally, G. longipinnis forms a clade together with G. ghorensis and G. jordanica. Hemigrammocapoeta culiciphaga, T. festai, H. nana, G. sahilia and G. smarti group together with Garra buettikerii and Garra tibanica, the latter two sharing the same ncRHO haplotype. Again the ML tree reconstruction confirms the topology of the $\mathrm{NJ}$ tree; support values of the nodes are similar (supplemental Fig. 5).

\section{Discussion}

This study was designed to examine the potential of the nuclear rhodopsin gene to improve DNA barcoding 




Figure 3: NJ-tree (Tamura 3-parameter model) derived from ncRHO sequences showing the traditional taxonomy. Bootstrap support values below $75 \%$ are hidden.

performance by resolving conflicts between morphological assignment and mitochondrial DNA data in cyprinid fishes. It is a direct comparison of genetic distances based on mtCOI and ncRHO in freshwater fishes, applied to cyprinids with low interspecific divergence, haplotype sharing, or presumed introgression, and to a specific case of taxonomic uncertainty in labeonine cyprinids of the Middle East.

\section{1 mtCOI vs. nuclear rhodopsin in cyprinids}

The present study revealed that the sequence variation within and among cyprinid species based on the nuclear rhodopsin marker is remarkable lower compared to the standard barcode region of mtCOI. Hence, we find less species discriminated by barcode gap when using ncRHO sequences compared to analyses based on mtCOI marker. The absence of a barcode gap between two species can have different reasons, as for instance haplotype sharing resulting from hybridization with or without introgression [14]. Even in the absence of hybridisation, young species pairs may share identical haplotypes due to incomplete lineage sorting [53]. Thus, recently radiated fish species, which have not been reproductively isolated for a long period of time may simply lack diagnostic mutations in 
the gene parts sequenced in this study [6]. The up to 10 times slower evolution rate of nuclear genes in contrast to mitochondrial DNA [54-57] has to be considered as most likely reason for the lack of barcode gaps.

Additionally, misidentification may produce apparent cases of common haplotypes, when specimens belonging to the same species are given different names [58]. Misidentification appears unlikely to cause the present conflicts, because all individuals were determined by taxonomic specialists, and the majority of the material is composed of adult specimens. An interesting example for a cyprinid species with high intraspecific variation combined with no barcode gap in our data is Mirogrex terrasanctae: Geiger et al. [10] point out that Mirogrex terrasanctae from Syria is distinguishable from Acanthobrama lissneri by morphological characters (see Goren et al. [59] for details). In their study based on mtCOI data alone, $M$. terrasanctae from Lake Muzarib, Syria was thought to be introgressed by Acanthobrama ([10]; Table $\mathrm{S2C}$ ), while $M$. terrasanctae from Lake Tiberias, Israel was well separated from Acanthobrama, indicating the need for a more detailed analysis. The nuclear rhodopsin marker results now reveal that both $M$. terrasanctae populations (Muzarib and Tiberias) cluster together as sister group to Acanthobrama (supplemental Figure S3). Intriguingly however, is the position of two Acanthobrama lissneri specimens from a Jordan River tributary in the vicinity of Lake Muzarib, which cluster in the ncRHO topology within Mirogrex. Apparently, admixture occurred between the two closely related (cf. [60]) genera near Lake Muzarib. While our M. terrasanctae samples from Lake Muzarib bear the Acanthobrama mitochondrial signature, the mitochondrial donors exhibit the nuclear Mirogrex signal. It would now be interesting to screen population genetic sample sizes for both, cyto-nuclear signature and morphological integrity of these populations, in comparison to pure stocks of the two species. While we present evidence for this introgression event, we do not know whether a complete sweep occurred and the population in the small Lake Muzarib $\left(0.5 \mathrm{~km}^{2}\right)$ now only possesses Acanthobrama mitochondria, or if there are still original haplotypes present in lower frequency.

In the minnow Phoxinus phoxinus, the intraspecific divergence of both markers exceeds the interspecific variance (mtCOI: $5.47 \%$ vs. $1.88 \%$; ncRHO: $0.26 \%$ vs. $0 \%$ ). As depicted in supplemental Figure S3, mtCOI haplotypes of this species form several (in toto non-monophyletic) clades. In contrast, the ncRHO haplotypes of this species cluster closely together, showing by far less genetic structure. We are currently conducting a separate study on the conspicuous Rhine minnow, where the discrepancy between deep mtCOI divergence and absence of ncRHO differentiation needs a careful examination before any conclusions can be drawn.

In the other cyprinid species where standard barcodes failed to offer unambiguous identification, the nuclear rhodopsin marker provides no additional benefit (Table 1). The direct comparison of both markers revealed that $76 \%$ of the 74 cyprinid species exhibit a clear barcode gap in the mtCOI gene, indicating lower levels of sequence variation within species in combination with differentiation between species. This is contrasted by only $39 \%$ of the all species showing a barcode gap using the nuclear rhodopsin marker. The significantly slower evolution of nuclear genes in contrast to mitochondrial markers is expected [54-57,61]. Nuclear markers might hence not be variable enough to distinguish closely related species but can help to resolve taxonomic uncertainties on a wider range. For the identification of cyprinids in the aquarium trade, nuclear rhodopsin data were found to be mostly consistent with mtCOI patterns and morphology [42]. This better performance may be due to the inclusion of rather unrelated species with higher interspecific divergence, creating barcode gaps [17]. However, although ncRHO proved to be useful to uncover interspecific hybridisation and unrecognized diversity in the aquarium species, the marker clearly failed to distinguish the more closely related species in the same study [42]. This is consistent with our results in cyprinids, corroborating that ncRHO is not sufficiently sensitive at the species level to distinguish closely related species. In French chubs (Squalius) mtCOI clearly separated the common chub S. cephalus from the Catalan chub $S$. laietanus with two divergent haplotype clusters [41], while nuclear rhodopsin sequences delivered nine different haplotypes with neither correspondence to taxonomy, nor to geography [41]. In our data, a number of chub species (Squalius orpheus, S. cappadocicus, S. cephalus, S. seyhanensis) share the same mtCOI and ncRHO haplotypes, which argues in favour of a common gene pool, rather than an admixture between separate entities (Fig. S3). The same situation was observerd in some rudd species (Scardinius erythrophthalmus, S. racovitzai, S. plotizza, S. scardafa, S. hesperidicus), gudgeons (Gobio hettitorum, G. microlepidotus) and nase (Chondrostma kubanicum, C. variabile). Yet, it is premature to derive any taxonomic conclusions from this and we recommend using the presented discrepancies between molecular and morphological entities to investigate the taxonomic implications for the above mentioned taxa in thorough systematic revisions. 


\section{2 $\mathrm{mtCOI}$ vs. nuclear rhodopsin in the labeonine cyprinids}

The comparison of the neighbour- joining tree topologies based on nuclear rhodopsin and mtCOI in labeonine cyprinids revealed no differences: irrespective of the marker chosen, the included species of Crossocheilus, Hemigrammocapoeta, Tylognathus and Typhlogarra were found to be nested in the genus Garra, which is morphologically characterized by the presence of the mental disc. Thus, as in Geiger et al. [10], Zheng et al. [29], Yang et al. [30], and Hamidan et al. [31] species lacking a mental disc (Hemigrammocapoeta, Crossocheilus, Tylognathus) are nested within groups presenting this diagnostic character state. With both markers, the two species G. rossica and G. variabilis with small and partly reduced mental disc group together with G. klatti (formerly Crossocheilus) and G. kemali (formerly Hemigrammocapoeta) lacking this diagnostic character. Most of the remaining 21 labeonine species are not well-resolved using the nuclear marker and again cluster together with species formerly placed in different genera (Hemigrammocapoeta (G. nana, G. culiciphaga), Crossocheilus (G. elegans), Tylognathus (G. festai) and Typhlogarra (G. widdowsoni)). We conclude that the patterns evident from mtCOI sequences were not mislead by introgression events, but are caused by an inadequate taxonomy in this group. The four labeonine genera (Tylognathus, Crossocheilus, Hemigrammocapoeta, Typhlogarra) lacking a mental disc have been traditionally placed under different genera, as the presence of this character is a diagnostic state for the genus Garra [28]. Our results support the hypothesis of Zheng et al. [29] that an evolution as well as a reduction of the mental disc occurred independently in several lineages in these species groups. According to this, we propose to transfer the species of the four labeonine genera lacking a mental disc to the genus Garra.

\section{Conclusions}

As one of the few studies directly comparing mtCOI with ncRHO in identical sets of individuals, our results suggest that ncRHO sequences are of little benefit for barcoding routines in cyprinids if species identification is the prime focus. Cases where standard mtCOI barcodes failed to offer unambiguous species identifications could not be resolved by using the nuclear gene. Most examined species exhibit lower levels of interspecific variation, most likely due to a slower evolutionary rate of the nuclear marker. Although failing to distinguish closely related species this marker is a useful indicator for taxonomic conflicts by providing supplementary information. In the labeonine cyprinids studied the distribution of nuclear rhodopsin genotypes is in congruence with the clustering of mitochondrial mtCOI haplotypes: based on both markers, the studied members of Crossocheilus, Hemigrammocapoeta, Tylognathus and Typhlogarra were found to be nested within the genus Garra, forming unique clusters for each species. These results suggest that patterns derived from mtCOI sequences were not mislead by introgression, but are most likely attributed to an inadequate taxonomy.

Acknowledgements: We thank numerous colleagues for providing additional samples, including Ignacio Doadrio, Maurice Kottelat, and Simon Walter. Claudia Etzbauer, Janine Schmidt, and Serkan Güse are acknowledged for help with logistics and wet-laboratory routines. Support came from the project FREDIE (Freshwater Diversity Identification for Europe, www.fredie.eu), funded by the Joint Initiative for Research and Innovation (PAKT) program of the German Leibniz Association. RŠ was supported by the Ministry of Culture of the Czech Republic (DKRVO 2015/15, National Museum, 00023272).

Conflict of interest: MSc Behrens-Chapuis reports grants from Leibniz association during the conduct of the study. Rest of the authors declares nothing to disclose.

\section{References}

[1] Ward R.D., Zemlak T.S., Innes B.H., Last P.R., Hebert P.D.N., DNA barcoding Australia's fish species, Philos. Trans. R. Soc. Lond. B Biol. Sci., 2005, 360, 1847-1857

[2] Wong E.H.K., Hanner R.H., DNA barcoding detects market substitution in North American seafood, Food Res. Int., 2008, $41,828-837$

[3] Steinke D., Zemlak T.S., Hebert P.D., Barcoding Nemo: DNA-based identifications for the ornamental fish trade, PLoS One, 2009, 4, e6300

[4] Kochzius M., Seidel C., Antoniou A., Botla S.K., Campo D., Cariani A., et al., Identifying fishes through DNA barcodes and microarrays, PLoS One, 2010, 5, e12620

[5] Ward R.D., Bronwyn H.H., William T.W., Last P.R., DNA barcoding Australasian chondrichthyans: results and potential uses in conservation, Mar. Freshwater Res., 2008, 59, 57-71

[6] Ward R.D., Hanner R., Hebert P.D.N., The campaign to DNA barcode all fishes, FISH-BOL, J. Fish Biol., 2009, 74, 329-356

[7] April J., Mayden R.L., Hanner R.H., Bernatchez L., Genetic calibration of species diversity among North America's freshwater fishes, Proc. Natl. Acad. Sci. USA, 2011, 108, 10602-10607 
[8] Zemlak T.S., Ward R.D., Connell A.D., Holmes B.H., Hebert P.D.N., DNA barcoding reveals overlooked marine fishes, Mol. Ecol. Resour., 2009, 9, 237-242

[9] Mabragaña E., Díaz de Astarloa J.M., Hanner R., Zhang J., González Castro M., DNA barcoding identifies Argentine fishes from marine and brackish waters, PLoS One, 2011, 6, e28655

[10] Geiger M.F., Herder F., Monaghan M.T., Almada V., Barbieri R., Bariche M., et al., Spatial heterogeneity in the mediterranean biodiversity hotspot affects barcoding accuracy of its freshwater fishes, Mol. Ecol. Resour., 2014, 14, 1210-1221

[11] Knebelsberger T., Landi M., Neumann H.H., Kloppmann M., Sell A. F., Campbell P.D., et al., A reliable DNA barcode reference library for the identification of the North European shelf fish fauna, Mol. Ecol. Resour., 2014, 14, 1060-1071

[12] Knebelsberger T., Dunz A.R., Neumann D., Geiger M.F., Molecular diversity of Germany's freshwater fishes and lampreys assessed by DNA barcoding, Mol. Ecol. Resour., 2015, 15, 562-572

[13] Lucentini L., Puletti M.E., Ricciolini C., Gigliarelli L., Fontaneto D., Lanfaloni L., et al., Molecular and phenotypic evidence of a new species of genus Esox (Esocidae, Esociformes, Actinopterygii): the southern pike, Esox flaviae, PloS One, 2011, 6, e25218

[14] Puckridge M., Andreakis N., Appleyard S.A., Ward R.D., Cryptic diversity in flathead fishes (Scorpaeniformes: Platycephalidae) across the Indo-West Pacific uncovered by DNA barcoding, Mol. Ecol. Resour., 2013, 13, 32-42

[15] Denys G.P.J., Dettai A., Persat H., Hautecœur M., Keith P., Morphological and molecular evidence of three species of pikes Esox spp. (Actinopterygii, Esocidae) in France, including the description of a new species, C. R. Biol., 2014, 337, 521-534

[16] Moritz C., Cicero C., DNA barcoding: promise and pitfalls, PLoS Biol., 2004, 2, e354

[17] Meyer C.P., Paulay G., DNA barcoding: error rates based on comprehensive sampling, PLoS Biol., 2005, 3, e422

[18] DeSalle R., Species Discovery versus Species Identification in DNA Barcoding Efforts: response to Rubinoff, Conserv. Biol., 2006, 20, 1545-1547

[19] Scribner K., Page K., Bartron M., Hybridization in freshwater fishes: a review of case studies and cytonuclear methods of biological inference, Rev. Fish Biol. Fish., 2000, 10, 293-323

[20] Salzburger W., Baric S., Sturmbauer C., Speciation via introgressive hybridization in East African cichlids?, Mol. Ecol., 2002, 11, 619-625

[21] Freyhof J., Lieckfeldt D., Pitra C., Ludwig A., Molecules and morphology: evidence for introgression of mitochondrial DNA in Dalmatian cyprinids, Mol. Phylogenet. Evol., 2005, 37, 347-354

[22] Aboim M.A., Mavarez J., Bernatchez L., Coelho M.M., Introgressive hybridization between two Iberian endemic cyprinid fish: a comparison between two independent hybrid zones, J. Evol. Biol., 2010, 23, 817-828

[23] Herder F., Schliewen U.K., Beyond sympatric speciation: Radiation of sailfin silverside fishes in the Malili Lakes (Sulawesi). In: Glaubrecht M. (Ed.), Evolution in Action Adaptive Radiations and the Origins of Biodiversity, 1st ed., Springer, Heidelberg, 2010

[24] Helfman G.S., Collete B.B., Facey D.E., The Diversity of Fishes, 3rd ed., Blackwell Scientific Publications, Malden, 1997
[25] Nelson J.S., Fishes of the World, 4th ed., Wiley \& Sons, New York, 2006

[26] Winfield I. J., Nelson, J. S., Cyprinid fishes: Systematics, biology and exploitation, 1st ed., Chapman \& Hall, London, 1991

[27] Howe K., Clark M. D., Torroja C. F., Torrance J., Berthelot C., Muffato M., et al., The zebrafish reference genome sequence and its relationship to the human genome, Nature, 2013, 496, 498-503

[28] Menon A.G.K., Monograph of the cyprinid fishes of the genus Garra Hamilton, Mem. Ind. Mus., 1964, 14, 173-260

[29] Zheng L., Junxing Y., Xiaoyong C., Phylogeny of the Labeoninae (Teleostei, Cypriniformes) based on nuclear DNA sequences and implications on character evolution and biogeography, Curr. Zool., 2012, 58, 837-850

[30] Yang L., Arunachalam M., Sado T., Levin B.A., Golubtsov A.S., Freyhof J., et al., Molecular phylogeny of the cyprinid tribe Labeonini (Teleostei: Cypriniformes), Mol. Phylogenet. Evol., 2012, 65, 362-379

[31] Hamidan N.A., Geiger M.F., Freyhof J., Garra jordanica, a new species from the Dead Sea basin with remarks on the relationship of G. ghorensis, G. tibanica and G. rufa (Teleostei: (yprinidae), Ichthyol. Explor. Freshwaters, 2014, 25, 223-236

[32] Monaghan M.T., Balke M., Gregory T.R., Vogler A.P., DNA-based species delineation in tropical beetles using mitochondrial and nuclear markers, Philos. Trans. R. Soc. Lond. B Biol. Sci., 2005, 360, 1925-1933

[33] Elias M., Hill R.I., Willmott K.R., Dasmahapatra K.K., Brower A.V.Z., Malllet J., et al., Limited performance of DNA barcoding in a diverse community of tropical butterflies, Proc. Biol. Sci., 2007, 274, 2881-2889

[34] Sonnenberg R., Nolte A.W., Tautz D., An evaluation of LSU rDNA D1-D2 sequences for their use in species identification, Front. Zool., 2007, 4, 6

[35] Vuataz L., Sartori M., Wagner A., Monaghan M.T., Toward a DNA taxonomy of alpine Rhithrogena (Ephemeroptera: Heptageniidae) using a mixed Yule-coalescent analysis of mitochondrial and nuclear DNA, PloS One, 2011, 6, e19728

[36] Venkatesh B., Ning Y., Brenner S., Late changes in spliceosomal introns define clades in vertebrate evolution, Proc. Natl. Acad. Sci. USA, 1999, 96, 10267-10271

[37] Sevilla R.G., Diez A., Norén M., Mouchel O., Jerome M., VerrezBagnis V., et al., Primers and polymerase chain reaction conditions for DNA barcoding teleost fish based on the mitochondrial cytochrome $b$ and nuclear rhodopsin genes, Mol. Ecol. Notes, 2007, 7, 730-734

[38] Chen W.J., Bonillo C., Lecointre G., Repeatability of clades as a criterion of reliability: a case study for molecular phylogeny of Acanthomorpha (Teleostei) with larger number of taxa, Mol. Phylogenet. Evol., 2003, 26, 262-288

[39] Chen W.J., Miya M., Saitoh K., Mayden R.L., Phylogenetic utility of two existing and four novel nuclear gene loci in reconstructing Tree of Life of ray-finned fishes: the order Cypriniformes (Ostariophysi) as a case study, Gene, 2008, 423, 125-134

[40] Hanner R., Floyd R., Bernard A., Collette B.B., Shivji M., DNA barcoding of billfishes, Mitochondrial DNA, 2011, 22, 27-36

[41] Denys G.P.J., Dettai A., Persat H., Doadrio I., Cruaud C., Keith P., Status of the Catalan chub Squalius laietanus (Actinopterygii, Cyprinidae) in France: input from morphological and molecular data, Knowl. Manag. Aquat. Ecosyst., 2013, 408, 04 
[42] Collins R.A., Armstrong K.F., Meier R., Yi Y., Brown S.D., Cruickshank R.H., et al., Barcoding and border biosecurity: identifying cyprinid fishes in the aquarium trade, PLoS One, 2012, 7, e28381

[43] Ivanova N.V., Zemlak T.S., Hanner R., Hebert P.D.N., Universal primer cocktails for fish DNA barcoding, Mol. Ecol. Notes, 2007, 7, 544-548

[44] Edgar R.C., MUSCLE: multiple sequence alignment with high accuracy and high throughput, Nucleic Acids Res., 2004, 32, 1792-1797

[45] Kearse M., Moir R., Wilson A., Stones-Hava S., Cheung M., Sturrock S., et al., Geneious Basic: an integrated and extendable desktop software platform for the organization and analysis of sequence data, Bioinformatics, 2012, 28, 1647-1649

[46] Brown S.D., Collins R., Boyer S., Lefort M.C., Malumbres-Olarte J., et al., Spider: an R package for the analysis of species identity and evolution, with particular reference to DNA barcoding, Mol. Ecol. Resour., 2012, 12, 562-565

[47] Collins R.A., Boykin L.M., Cruickshank R.H., Armstrong K.F., Barcoding's next top model: an evaluation of nucleotide substitution models for specimen identification, Methods Ecol. Evol., 2012, 3, 457-465

[48] Srivathsan A., Meier R., On the inappropriate use of Kimura-2parameter (K2P) divergences in the DNA-barcoding literature, Cladistics, 2012, 28, 190-194

[49] Kimura M., A simple method for estimating evolutionary rates of base substitutions through comparative studies of nucleotide sequences, J. Mol. Evol., 1980, 16, 111-120

[50] Tamura K., Stecher G., Peterson D., Filipski A., Kumar, S., MEGA6: molecular evolutionary genetics analysis version 6.0., Mol. Biol. Evol., 2013, 30, 2725-2729

[51] Posada D., Crandall, K.A., MODELTEST: testing the model of DNA substitution, Bioinformatics, 1998, 14, 817-818

[52] Tamura K., Estimation of the number of nucleotide substitutions when there are strong transition-transversion and $\mathrm{G}+\mathrm{C}$ content biases, Mol. Biol. Evol., 1992, 9, 4, 678-687
[53] Hubert N., Hanner R., Holm E., Mandrak N.E., Taylor E., Burridge M., et al., Identifying Canadian freshwater fishes through DNA barcodes, PloS One, 2008, 3, e2490

[54] Brown W.M., George M.Jr., Wilson A.C., Rapid evolution of animal mitochondrial DNA, Proc. Natl. Acad. Sci. USA, 1979, 76, 1967-1971

[55] Brown W.M., Prager E.M., Wang A., Wilson A.C., Mitochondrial DNA sequences of primates: tempo and mode of evolution, J. Mol. Evol., 1982, 18, 225-239

[56] Brown W.M., Evolution of animal mitochondrial DNA, In: Nei M., Koehn R.K. (Eds.), Evolution of genes and proteins, 1st ed., Sinauer Associates, Sunderland, 1983

[57] Moritz C., Dowling T.E., Brown W.M., Evolution of animal mitochondrial DNA: relevance for population biology and systematics, Annu. Rev. Ecol. Syst., 1987, 18, 269-292

[58] Bortolus A., Error cascades in the biological sciences: the unwanted consequences of using bad taxonomy in ecology, Ambio, 2008, 37, 114-118

[59] Goren M., Fishelson L., Trewavas E., The cyprinid fishes of Acanthobrama Heckel and related genera, Bull. Br. Mus. Nat. Hist. Zool., 1973, 24, 293-315

[60] Perea S., Böhme M., Zupančič P., Freyhof J., Šanda R., Özuluğ M., et al., Phylogenetic relationships and biogeographical patterns in Circum-Mediterranean subfamily Leuciscinae (Teleostei, Cyprinidae) inferred from both mitochondrial and nuclear data, BMC Evol. Biol., 2010, 10, 265

[61] Lautredou A.C., Bonillo C., Denys G., Cruaud C., Ozouf-Costaz C., Lecointre G., et al., Molecular taxonomy and identification within the Antarctic genus Trematomus (Notothenioidei, Teleostei): How valuable is barcoding with COI?, Polar Sci., 2010, 4, 333-352

Supplemental Material: The online version of this article (DOI: 10.1515/dna-2015-0020) offers supplementary material. 